\title{
Faunal communities of the field stratum and their succession in reserved fields
}

\author{
Heikki Hokkanen and Mikno Raatikainen \\ University of Jyväskylä, Department of Biology \\ Yliopistonkatu 9, 40100 Jyväskylä 10, Finland
}

\begin{abstract}
The arthropod of the field stratum and small mammal fauna of 51 reserved fields were studied in Central Finland in 1974. In high summer the arthropod density was on the average 210 individuals $/ \mathrm{m}^{2}$, of which Auchenorrhyncha formed $42 \%$, Hymenoptera $18 \%$. Coleoptera $14 \%$, and others $26 \%$. Arthropods were more abundant in fields that had been reserved after leys than in fields after open cultivations. The abundance of most arthropod taxa increased as the time in reservation increased. However, the abundance of most pests of any significance decreased with years.

Sorex araneus L. and Microtus agrestis L. formed almost $90 \%$ of the small mammal fauna of the fields. Their abundance was on the average much less than in the Scots pine seed orchards nearby.

The leafhopper faunas were divided into three communities. One appeared in young (1st-3rd year) fields, and the other two in older (2nd-6th year) fields, one in dry and one in moist fields. The Apion fauna was divided into four communities. The dependence of the described arthropod communities on the vegetational communities of the fields was weak, although some relationships were observable.
\end{abstract}

\section{Introduction}

To decrease the area under cultivation, the Field Reservation Act (216/ 1969) was enacted in 1969. By the end of 1974 about $8 \%$ of the cultivated area in Finland had been reserved (Anov. 1975). Research on the flora and fauna of reserved fields was started in the University of Jyväskylä in 1973. Several papers have been published on the subject, e.g. TÖRMÄLÄ and НоккANen (1976), Törmälä and RaAtikainen (1976), Hokkanen and RaAtikainen (1977), TÖRMÄLÄ (1977). The purpose of this study is to identify the most important animal taxa and faunal communities of the field stratum, as well as their succession in reserved fields.

Relatively little information about the fauna of reserved or abandoned fields in Finland is presented in the literature, the works of Gyllenberg (1969), Koponen (1972), TÖRMÄLÄ and RAATIKAINEN (1976) and TörmäLÄ (1977) are almost the only ones from Finland. Much more is known about the fauna of cultivated fields, although most works deal only with one distinct group of animals. E.g. Mark kula and Myllymäki (1958), RaAtikainen (1971), Huhta 
and RaAtikainen (1974), Laitinen and RaAtikainen (1975), and RaAtikainen and VASARAINEN (1976) present information from Finland; similar studies have been made e.g. in Sweden (JürIsoo 1964) and Poland (ANDrZEJEwSKA 1971, KaJAK et al. 1971, OLechowicz 1971, etc).

\section{Material and methods}

\subsection{Study area}

The study area consisted of the following communes: Jyväskylä, the rural commune of Jyväskylä, Petäjävesi and Uurainen (about $62^{\circ} \mathrm{N}$ and $25^{\circ} \mathrm{E}$ ) in Central Finland. 20 reserved farms were selected at random, and from each $2-3$ homogenous fields again at random. Thus 51 fields were obtained, which were reserved as follows: 13 in 1969 (=6th year fields), 5 in 1970, 6 in 1971, 11 in 1972, 10 in 1973 and 6 in 1974 (=1st year fields). Further details about the fields and the study area are given in HoKKANEN and RAATIKAINEN (1977).

\subsection{Sampling}

Arthropods were sampled in early summer (4-11. VI 1974) with standard sweep-nets described by Heikinheimo and RaAtikainen (1962). Four samples, 15 sweeps each, were taken from each field between 10 a.m. and 4 p.m. The samples were not taken if it was rainy or if there was a gale, or the vegetation was wet. The animals were killed with diethyl ether, stored in a dry place, and sorted later by hand according to species (the most numerous or otherwise important species) or group.

In high summer $(16-24$. VII 1974) quantitative samples were taken with Burkard suction apparatus from a circular metal enclosure with an area of $0.10 \mathrm{~m}^{2}$ placed on the ground. A suction time of 1.5 minutes was used. 4 randomly located samples were taken from each field, they were treated in the same way as the sweep-net samples. The nomenclature of Auchenorrhyncha is according to Linnavuorr (1969), and that of the Apions according to Hansen (1965)

The abundance of small mammals was studied with the small quadratmethod described by MYLLymäKI et al. (1971). Trapping was conducted between $21-26$. VIII. 1974 so that one quadrat was located per field. The whole material consisted of the catch from 1224 trap-nights. The nomenclature of small mammals is according to SIrvonen (1974).

\subsection{Treatment of data}

Faunal communities were differentiated by means of the modified Sørensen's quotient of similarity:

$$
\mathrm{QS}=100 \times \frac{\Sigma 2 \mathrm{c}}{\sum(\mathrm{a}+\mathrm{b})}, \text { where }
$$

$\mathrm{a}=$ the amount of a species in sample 1

$\mathrm{b}=$ the amount of the same species in sample 2

$\mathrm{c}=$ the smaller of these two values $(\mathrm{a}$ and $\mathrm{b})$

The following symbols for the levels of significance are used in all the tests: $\mathrm{p}^{*}<0.05, \mathrm{p}^{* *}<0.01, \mathrm{p}^{* * *}<0.001$. 


\section{Results}

\subsection{Taxa, their occurrence and abundance}

3. 1. 1. Arthropods

The 202 sweep-net samples which were taken, contained a total of 13640 arthropod specimens. Table 1 shows the number of individuals in the different arthropod taxa/60 sweeps, according to different age classes and previous use

Table 1. Number of arthropods in sweep-net samples according to the age and previous use of the fields. $1-6=$ age as a reserved field in years, $\mathrm{O}=$ fields reserved after open cultivations, $\mathrm{L}=$ fields reserved after ley or pasture, $\mathrm{n}=$ number of samples.

\begin{tabular}{|c|c|c|c|c|c|c|c|c|c|c|c|c|}
\hline \multirow{2}{*}{ Taxon } & \multicolumn{8}{|c|}{ Number of individuals/60 sweeps } & \multirow[b]{2}{*}{ L3 } & \multirow[b]{2}{*}{ L4 -5} & \multirow[b]{2}{*}{ L6 } & \multirow{2}{*}{$\begin{array}{r}\text { All } \\
\text { fields }\end{array}$} \\
\hline & 01 & 02 & 03 & 04 & 05 & 06 & L1 & L2 & & & & \\
\hline Araneida ................. & 2.5 & 22.3 & 14.9 & 12.0 & 23.7 & 21.5 & 11.5 & 12.3 & 16.0 & 20.0 & 25.3 & 17.0 \\
\hline Phalangida ............... & - & - & 0.1 & - & - & - & - & - & - & - & - & 0.0 \\
\hline Ephemeroptera .......... & - & - & 0.6 & - & 0.3 & 0.2 & 0.5 & - & 2.0 & - & - & 0.3 \\
\hline Plecoptera ................ & - & 0.8 & 0.1 & - & - & - & - & - & - & - & - & 0.1 \\
\hline Orthoptera ................. & 0.8 & 0.3 & 0.1 & 2.5 & 2.7 & 1.2 & - & 0.2 & 1.0 & 0.8 & 1.7 & 1.0 \\
\hline Thysanoptera ............ & 5.3 & 3.8 & 7.3 & 42.0 & 25.3 & 2.2 & 1.0 & 154.3 & 125.3 & 8.8 & 4.1 & 36.0 \\
\hline \multicolumn{13}{|c|}{ Homoptera } \\
\hline Auchenorrhyncha .... & 1.8 & 10.8 & 14.4 & 27.0 & 40.4 & 64.2 & 18.5 & 42.7 & 34.5 & 72.3 & 111.0 & 44.1 \\
\hline $\begin{array}{l}\text { Balclutha punctata. } \\
\text { Diplocolenus abdo- }\end{array}$ & 0.3 & 2.5 & 10.7 & 4.5 & 22.7 & 4.7 & 8.0 & 9.0 & 0.3 & 3.0 & 3.1 & 6.0 \\
\hline minalis ............. & - & 2.3 & - & 3.5 & 3.7 & 5.5 & - & 10.7 & 8.5 & 6.3 & 22.0 & 6.7 \\
\hline Doliotettix pallens. & - & 2.3 & 0.9 & 9.0 & 2.0 & 38.2 & 2.5 & 7.2 & 15.1 & 42.3 & 47.0 & 17.5 \\
\hline $\begin{array}{l}\text { Javesella spp } \ldots . . . \\
\text { Megadelphax sordi- }\end{array}$ & 1.0 & - & 0.3 & 3.0 & 1.3 & 2.0 & 2.5 & 4.2 & 0.3 & 1.8 & 3.4 & 1.9 \\
\hline dula .................. & - & 3.0 & 0.7 & 5.5 & 4.4 & 4.5 & 3.5 & 6.8 & 9.1 & 4.8 & 28.2 & 7.5 \\
\hline Stiroma bicarinata & - & 0.5 & - & - & 1.0 & 6.2 & - & 0.2 & - & 10.8 & 3.9 & 2.2 \\
\hline Psyllina $\quad . . \ldots \ldots . . . . . .$. & 5.5 & 2.5 & 6.1 & 4.8 & 39.3 & 3.8 & 1.5 & 3.8 & 4.0 & 3.5 & 3.3 & 6.2 \\
\hline Heteroptera ............... & 4.0 & 12.8 & 3.5 & 10.1 & 64.7 & 10.3 & 21.0 & 8.9 & 12.1 & 22.8 & 10.2 & 13.6 \\
\hline Coleoptera ................ & 5.6 & 19.0 & 17.7 & 29.3 & 68.0 & 67.8 & 28.0 & 33.5 & 137.3 & 74.5 & 45.6 & 46.5 \\
\hline Apion spp. ......... & 0.3 & 3.5 & 3.0 & 3.5 & 5.0 & 2.7 & 1.0 & 5.7 & 1.5 & 9.8 & 5.4 & 3.9 \\
\hline Chaetocnema spp . & 1.0 & 0.5 & 1.3 & - & - & - & - & 2.7 & - & 0.3 & - & 0.6 \\
\hline Longitarsus spp. ... & 0.3 & 1.8 & 2.0 & - & c.3 & - & - & 1.2 & - & 0.3 & - & 0.6 \\
\hline Phyllotreta spp. ... & 1.0 & 1.0 & 0.9 & - & - & 0.3 & 1.5 & 1.8 & 0.3 & - & - & 0.6 \\
\hline Sitona spp. .......... & 0.3 & 1.8 & 0.6 & - & 3.0 & 0.7 & 1.5 & 0.2 & - & 1.3 & 1.9 & 0.9 \\
\hline Galerucella tenella. & - & - & - & 5.5 & 9.3 & 3.3 & 15.0 & 0.2 & 1.3 & 52.3 & 7.9 & 7.3 \\
\hline Polydrosus mollis... & - & 2.0 & 2.3 & 12.0 & 3.7 & 50.2 & - & 7.7 & 128.0 & 1.8 & 8.1 & 19.7 \\
\hline Agriotes obscurus... & - & - & - & 0.3 & - & - & - & 0.2 & - & - & - & 0.0 \\
\hline Corymbites incanus & - & - & 1.4 & - & - & - & - & 0.3 & - & - & - & 0.2 \\
\hline C. pectinicornis .... & - & 0.3 & - & - & - & - & - & 0.2 & - & 0.3 & - & 0.1 \\
\hline Dolopius margina- & & & & & & & & & & & & \\
\hline tus ................... & - & - & - & 0.3 & 0.3 & 0.2 & - & 0.5 & - & - & - & 0.1 \\
\hline Hymenoptera ............. & 3.0 & 14.0 & 12.1 & 26.3 & 100.0 & 37.7 & 16.5 & 61.5 & 31.0 & 59.0 & 28.7 & 34.3 \\
\hline Lepidoptera ................ & - & - & 0.1 & 1.3 & 1.0 & 0.5 & - & 0.5 & 0.3 & 0.5 & 0.4 & 0.4 \\
\hline Diptera ....................... & 30.3 & 54.0 & 39.7 & 45.8 & 83.3 & 72.5 & 152.0 & 154.2 & 39.8 & 58.0 & 35.0 & 65.6 \\
\hline Amaurosoma armil- & & & & & & & & & & & & \\
\hline latum $\quad . . . . . . . . . .$. & - & 0.3 & 0.6 & 1.8 & - & 0.5 & 1.5 & 2.2 & 1.0 & 1.3 & 0.6 & 0.9 \\
\hline A. flavipes .......... & 0.5 & 8.8 & 4.1 & 3.5 & 4.0 & 1.3 & 1.0 & 6.0 & 7.3 & 5.0 & 1.1 & 3.8 \\
\hline Insecta, larvae ........... & 0.5 & 0.8 & 1.1 & 4.8 & 5.0 & 2.3 & 5.0 & 1.7 & 2.5 & 4.3 & 2.1 & 2.4 \\
\hline 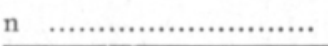 & 16 & 16 & 28 & 15 & 12 & 23 & 8 & 24 & 16 & 16 & 28 & 202 \\
\hline
\end{tabular}


Table 2. Number of arthropods in suction samples. Explanations as in Table 1.

\begin{tabular}{|c|c|c|c|c|c|c|c|c|c|c|c|c|}
\hline \multirow{2}{*}{ Taxon } & \multicolumn{11}{|c|}{ Number of individuals $/ \mathrm{m}^{2}$} & \multirow{2}{*}{$\begin{array}{c}\text { All } \\
\text { fields }\end{array}$} \\
\hline & O1 & $\mathrm{O} 2$ & $\mathrm{O} 3$ & O4 & O5 & O6 & L1 & L2 & L3 & $\mathrm{L} 4-5$ & L6 & \\
\hline Araneida .................... & 4.4 & 12.5 & 8.2 & 15.6 & 41.7 & 14.6 & 8.8 & 12.9 & 20.6 & 20.0 & 23.6 & 16.1 \\
\hline Phalangida ................. & - & 0.6 & 0.4 & - & - & - & - & - & 0.6 & - & - & 0.2 \\
\hline Ephemeroptera ........... & - & - & 0.4 & - & - & - & - & - & - & - & - & 0.0 \\
\hline Plecoptera.............. & - & 0.2 & - & - & - & - & - & - & - & - & 0.7 & 0.1 \\
\hline Orthoptera ................. & - & - & - & - & - & - & - & - & 0.6 & - & 0.4 & 0.1 \\
\hline Thysanoptera ............. & 6.9 & - & - & - & 2.5 & - & - & 0.4 & 3.1 & - & 0.4 & 1.0 \\
\hline \multicolumn{13}{|l|}{$\begin{array}{l}\text { Homoptera } \\
\text { Auchenorrhyncha, lar- }\end{array}$} \\
\hline vae $\ldots \ldots \ldots \ldots \ldots$ & 3.1 & 33.1 & 19.3 & 54.4 & 57.5 & 38.3 & 46.3 & 30.8 & 80.0 & 68.1 & 73.9 & 44.9 \\
\hline Agallia spp .......... & 0.6 & 5.6 & 1.8 & 0.6 & 4.2 & 3.6 & 1.3 & - & 1.9 & 2.5 & 2.9 & 2.3 \\
\hline \multicolumn{13}{|l|}{ Auchenorrhyncha, } \\
\hline adults $\ldots \ldots \ldots \ldots \ldots$ & 6.9 & 41.3 & 27.9 & 47.5 & 33.3 & 27.5 & 17.5 & 25.8 & 51.9 & 96.9 & 79.3 & 42.8 \\
\hline Aphrodes bifasciatus & 0.6 & 1.9 & 1.1 & 1.9 & 5.8 & - & - & 3.8 & 5.6 & - & 1.4 & 1.9 \\
\hline \multicolumn{13}{|c|}{ Arthaldeus pascuel- } \\
\hline lus .................. & - & 0.8 & 0.6 & 1.3 & - & 0.8 & 1.0 & 0.8 & 5.0 & 4.3 & 3.7 & 1.7 \\
\hline $\begin{array}{l}\text { Dicranotropis ha- } \\
\text { mata ................ } \\
\text { Diplocolenus abdo- }\end{array}$ & - & - & - & 3.1 & 1.7 & 0.8 & - & - & 3.8 & 4.4 & 0.7 & 1.2 \\
\hline $\begin{array}{c}\text { Diplocolenus abdo- } \\
\text { minalis .............. }\end{array}$ & 1.3 & 11.9 & 5.7 & 15.0 & 9.2 & 12.1 & 6.3 & 4.2 & 15.6 & 31.3 & 27.1 & 13.1 \\
\hline Doratura stylata ... & - & - & - & - & 0.8 & 0.4 & - & - & - & 3.1 & 4.3 & 0.9 \\
\hline Elymana sulphurella & - & 0.6 & 4.3 & - & - & 0.4 & - & 0.4 & 0.6 & 2.5 & 5.0 & 1.7 \\
\hline Evacanthus inter- & & & & & & & & & & & & \\
\hline ruptus ............... & 0.6 & 6.3 & 6.8 & 10.6 & 3.3 & 1.7 & 3.8 & 4.2 & 6.3 & 5.0 & 3.6 & 4.7 \\
\hline Paluda flaveola .... & - & - & - & 10.6 & 9.2 & 3.8 & - & 1.7 & 3.8 & 29.4 & 17.1 & 7.0 \\
\hline P. preyssleri ........ & - & 0.6 & - & 1.3 & 0.8 & 2.5 & - & - & - & 4.4 & 5.0 & 1.5 \\
\hline $\begin{array}{c}\text { Philaenus spuma- } \\
\quad \text { rius .................... }\end{array}$ & & & & & & & & & & & & \\
\hline Stiroma bicarinata. & - & 1.3 & 0.4 & 6.3 & 0.8 & 1.7 & 1.3 & 0.4 & 1.3 & 5.0 & 5 & 8 \\
\hline Streptanus sordidus & 0.6 & 3.1 & 1.4 & 3.1 & - & 0.4 & 5.0 & 1.3 & 4.4 & 3.8 & 7.5 & 2.8 \\
\hline Xanthodelphax fla & & & & & & & & & & & & \\
\hline veola...$\ldots \ldots \ldots \ldots$ & - & 0.6 & 0.4 & 0.6 & 9.2 & 0.4 & - & - & - & 1.9 & 3.6 & 1.4 \\
\hline Aphidina $\quad \cdots . . . . . . . . .$. & 0.6 & - & - & - & 3.1 & - & 1.3 & 0.4 & 3.1 & - & 0.7 & 0.7 \\
\hline Psyllina ................. & - & 0.6 & 1.4 & - & 0.8 & - & - & - & 1.9 & - & 0.7 & 0.5 \\
\hline Heteroptera ................ & 1.9 & 12.5 & 3.9 & 23.8 & 32.5 & 18.8 & 15.1 & 14.6 & 25.1 & 36.9 & 24.7 & 18.2 \\
\hline Coleoptera................ & 33.1 & 20.0 & 16.8 & 21.2 & 29.2 & 42.1 & 26.3 & 14.6 & 14.4 & 84.4 & 24.3 & 28.6 \\
\hline Apion spp ............ & - & 8.8 & 7.5 & 8.8 & 10.8 & 6.7 & 2.5 & 10.8 & 3.1 & 24.4 & 12.9 & 9.1 \\
\hline A. apricans ......... & - & 3.8 & 2.1 & 0.6 & - & - & 1.3 & 2.5 & - & 0.6 & 4.3 & 1.6 \\
\hline A. cerdo ............... & - & - & 0.4 & 2.5 & 1.7 & - & - & - & - & 1.9 & 0.4 & 0.5 \\
\hline A. curtirostre $\ldots . .$. & - & - & 0.7 & 1.3 & 0.8 & 2.1 & 1.3 & - & 0.6 & 1.3 & 0.7 & 0.8 \\
\hline A. facetum ........... & 一 & - & - & 1.9 & 5.8 & 0.4 & - & - & - & 6.9 & 1.1 & 1.2 \\
\hline A. flavipes ......... & - & 0.6 & 0.4 & - & 0.8 & - & - & 0.8 & - & 0.6 & 2.1 & 0.6 \\
\hline A. simile .............. & - & 1.9 & 1.8 & 0.6 & 0.8 & 1.3 & - & 5.8 & 0.6 & 1.9 & 0.4 & 1.6 \\
\hline A. viciae $\ldots . . . \ldots \ldots$ & - & - & 1.1 & 1.9 & 0.8 & 0.8 & - & 0.4 & 1.3 & 7.5 & 1.4 & 1.4 \\
\hline Hymenoptera .............. & 25.0 & 14.3 & 13.2 & 9.4 & 65.0 & 20.0 & 17.5 & 25.4 & 20.0 & 70.6 & 110.7 & 37.8 \\
\hline Formicoidea ............. & 3.1 & 4.4 & 5.7 & 1.3 & 15.8 & 5.4 & 7.6 & 17.2 & 6.9 & 32.5 & 100.7 & 21.0 \\
\hline Lasius niger .......... & - & 3.8 & 2.5 & - & 3.3 & 0.4 & - & 6.7 & - & 0.6 & 1.4 & 1.9 \\
\hline Myrmica laevinodis & 3.1 & 0.6 & 3.2 & 1.3 & 11.7 & 5.0 & 6.3 & 1.7 & 5.6 & 22.5 & 98.9 & 18.3 \\
\hline Lepidoptera ................ & - & 2.0 & - & - & - & 1.7 & - & - & - & 2.5 & 1.1 & 0.7 \\
\hline Diptera ...................... & 20.0 & 22.5 & 20.7 & 16.3 & 13.3 & 6.3 & 12.5 & 13.8 & 12.5 & 14.4 & 10.4 & 14.6 \\
\hline Insecta, larvae ........... & - & 3.8 & 5.0 & 8.1 & 5.0 & 2.1 & 6.3 & 5.0 & 1.3 & 1.3 & 2.5 & 3.5 \\
\hline n $\quad$ n.w. & 16 & 14 & 27 & 16 & 12 & 22 & 8 & 20 & 14 & 16 & 28 & 193 \\
\hline
\end{tabular}


of the fields. The 193 suction samples contained 4280 specimens. According to Table 2, the most abundant group was Auchenorrhyncha. Second in abundance was Hymenoptera, mainly because of Myrmica laevinodis.

The numbers of individuals of the most important species or families of Auchenorrhyncha and Coleoptera are given in Tables 1 and 2. Table 3 shows also the frequencies of some pest groups in sweep-net samples.

Table 3. Frequencies (\%) of some pest-groups in sweep-net samples (early June). Explanations as in Table 1.

\begin{tabular}{|c|c|c|c|c|c|c|c|c|c|c|c|c|}
\hline Taxon & 01 & 02 & 03 & 04 & 05 & 06 & L1 & L2 & L3 & $\mathrm{L} 4-5$ & L6 & $\begin{array}{c}\text { All } \\
\text { fields }\end{array}$ \\
\hline Chaetocnema spp. ...... & 25 & 13 & 25 & - & - & - & - & 33 & - & 6 & - & 11 \\
\hline Longitarsus spp. ........ & 6 & 31 & 25 & - & 8 & - & - & 29 & - & 6 & - & 11 \\
\hline Phyllotreta spp. ....... & 19 & 25 & 21 & - & - & 9 & 13 & 17 & 19 & - & - & 11 \\
\hline Sitona spp. .............. & 6 & 31 & 14 & - & 33 & 17 & 25 & 4 & - & 31 & 36 & 18 \\
\hline Elateridae .............. & - & 6 & 21 & 13 & 8 & 4 & - & 30 & - & 6 & - & 9 \\
\hline Galerucella tenella ...... & - & - & - & 40 & 50 & 17 & 25 & 5 & 13 & 50 & 32 & 19 \\
\hline $\begin{array}{l}\text { Polydrosus mollis ....... } \\
\text { Amaurosoma }\end{array}$ & - & 19 & 25 & 53 & 33 & 57 & - & 45 & 25 & 31 & 50 & 33 \\
\hline armillatum ............. & - & 6 & 14 & 27 & - & 13 & 13 & 50 & 19 & 31 & 14 & 18 \\
\hline A. flavipes............. & 13 & 94 & 46 & 60 & 58 & 35 & 25 & 55 & 81 & 69 & 21 & 49 \\
\hline 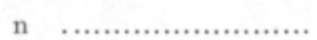 & 16 & 16 & 28 & 15 & 12 & 23 & 8 & 24 & 16 & 16 & 28 & 202 \\
\hline
\end{tabular}

\section{1.2. $\mathrm{Small} \mathrm{mammals}$}

The total catch of small mammals was 167 individuals, 13.6 per 100 trapnights. The species composition and other data are given in Table 4. Sorex araneus and Microtus agrestis formed about $90 \%$ of the total catch, other species occurred only accidentally. On $16 \%$ of the quadrats the catch of small mammals was zero individuals, one individual was caught on $14 \%$ of the quadrats, two on $22 \%$, three on $2 \%$, four on $18 \%$, five on $10 \%$, six on $6 \%$, seven on $2 \%$, eight on $4 \%$, and ten, eleven or twelve individuals per quadrat each on $2 \%$ of them.

Table 4. The catches of small mammals. $n=$ number of captured indiiduals, $F \%=$ frequency$\%$ in quadrats, $\bar{x}=$ average number of individuals per quadrat, $\mathrm{N}=$ number of individuals per 100 trap-nights.

\begin{tabular}{|c|c|c|c|c|}
\hline & $\mathrm{n}$ & $\mathrm{F} \%$ & $\overline{\mathbf{x}}$ & $\mathbf{N}$ \\
\hline Sorex araneus ................................. & 96 & 80 & 1.9 & 7.8 \\
\hline Microtus agrestis ............................ & 53 & 38 & 1.0 & 4.3 \\
\hline Clethrionomys glareolus ....................... & 6 & 6 & 0.1 & 0.5 \\
\hline Micromys minutus .......................... & 3 & 6 & 0.1 & 0.3 \\
\hline 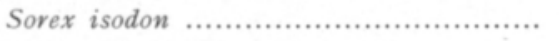 & 3 & 6 & 0.1 & 0.3 \\
\hline Neomys fodiens ............................ & 2 & 4 & 0.0 & 0.2 \\
\hline Arvicola terrestris ............................. & 2 & 2 & 0.0 & 0.2 \\
\hline Apodemus flavicollis ....................... & 2 & 2 & 0.0 & 0.2 \\
\hline 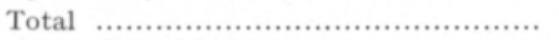 & 167 & 84 & 3.3 & 13.6 \\
\hline
\end{tabular}




\section{2. Factors affecting abundances}

Tables $1-3$ and Fig. 1 show the changes in the abundances of the main taxa as a function of the age of the field (as a reserved field). According to the results of the sweep-net samples, the abundances of Auchenorrhyncha $\left(\mathrm{r}=.587^{* * *}\right)$, Araneida $\left(.443^{* *}\right)$, Hymenoptera $\left(.430^{* *}\right)$, Coleoptera $\left(.395^{* *}\right)$, and Heteroptera $\left(.364^{*}\right)$ increase with time. The only negative correlations observed, were: Phyllotreta spp. $\left(-.498^{* * *}\right)$, Chaetocnema spp. $\left(-.385^{* *}\right)$, and Longitarsus spp. $\left(-.283^{*}\right)$. Results of the suction samples also showed significant positive correlations with age for Auchenorrhyncha $\left(.440^{* *}\right)$, Araneida $\left(.432^{* *}\right)$, and Heteroptera $\left(.356^{*}\right)$, and a negative one for Diptera $\left(-.402^{* *}\right)$ (Fig. 1).

As to the previous use of the fields, leafhoppers and bugs were significantly more abundant on fields that had been reserved after leys or pastures than on fields after open cultivations. No taxon was significantly more abundant after open cultivations than after leys.

The moisture conditions of the fields were evaluated, and some groups showed differences in abundance according to the wetness of the field. For arthropods, all the correlations showed greater abundance on drier fields, whereas small mammals were more abundant on moist fields $\left(.334^{*}\right)$. Coleoptera $\left(.374^{* *}\right)$, Thysanoptera $\left(.336^{*}\right)$, Heteroptera $\left(.342^{*}\right)$ and some Auchenorrhyncha species (Dicranotropis hamata .421**, Doratura stylata .347**, Elymana sulphurella .290*) showed a greater tendency towards drier conditions than the average.

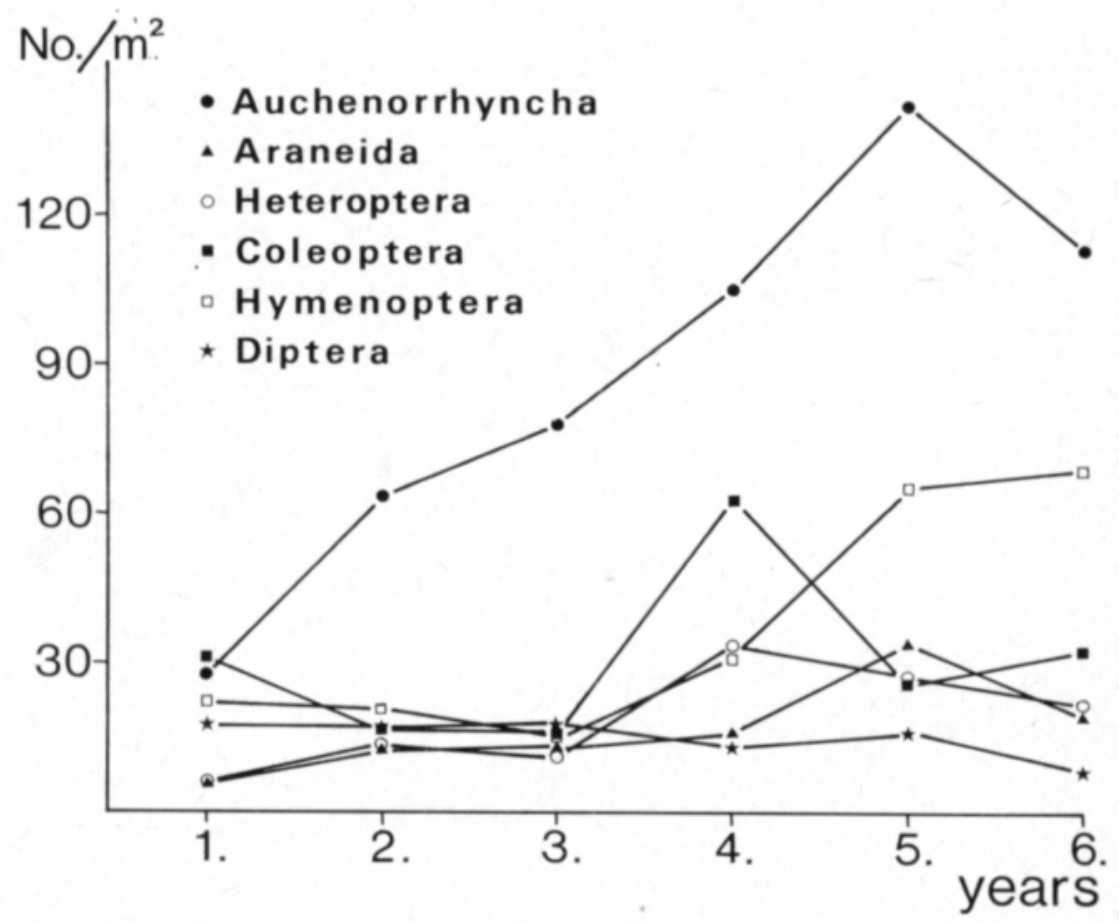

Fig. 1. Abundances of the main Arthropod taxa in mid-summer, according to the age of the fields as a reserved field. 


\subsection{Communities}

3. 3. 1. D es cription

The leafhopper data of the sweep-net and the suction samples and the Apion data of the suction samples were treated with the Sørensen's quotient of similarity method to differentiate seasonal aspects and communities. Three early summer aspects could be recognized from the leafhopper fauna of the sweep-net samples; their species composition, dominance relations, and succession are given in Table $\mathbf{5}$ and Fig. 2.

1) Balclutha punctata aspect appeared mainly on 1st-3rd year fields, which were situated usually on coarse mineral ground. Balclutha, which hiberna-

Table 5. Dominance relations in the early summer aspects of leafhopper communities. $\mathrm{A}=$ Balclutha punctata aspect, $\mathrm{B}=$ Megadelphax sordidula aspect, $\mathrm{C}=$ Doliotettix pallens aspect, $\mathrm{n}=$ number of leafhoppers on the average.

\begin{tabular}{|c|c|c|c|}
\hline & A & B & C \\
\hline 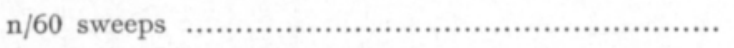 & 17.0 & 24.7 & 128.9 \\
\hline \multicolumn{4}{|l|}{ Dominance $\%$} \\
\hline Balclutha punctata ............................. & 64 & 19 & 3 \\
\hline 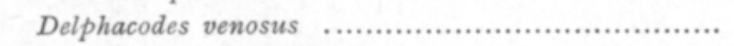 & 0 & - & 0 \\
\hline 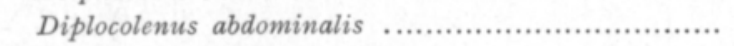 & 5 & 27 & 11 \\
\hline Doliotettix pallens ........................................ & 10 & 19 & 69 \\
\hline Javesella spp. . ...................................... & 15 & 3 & 2 \\
\hline 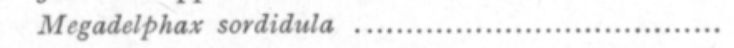 & 6 & 30 & 9 \\
\hline 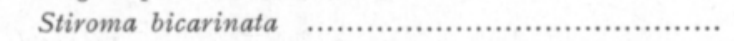 & 1 & 1 & 6 \\
\hline
\end{tabular}

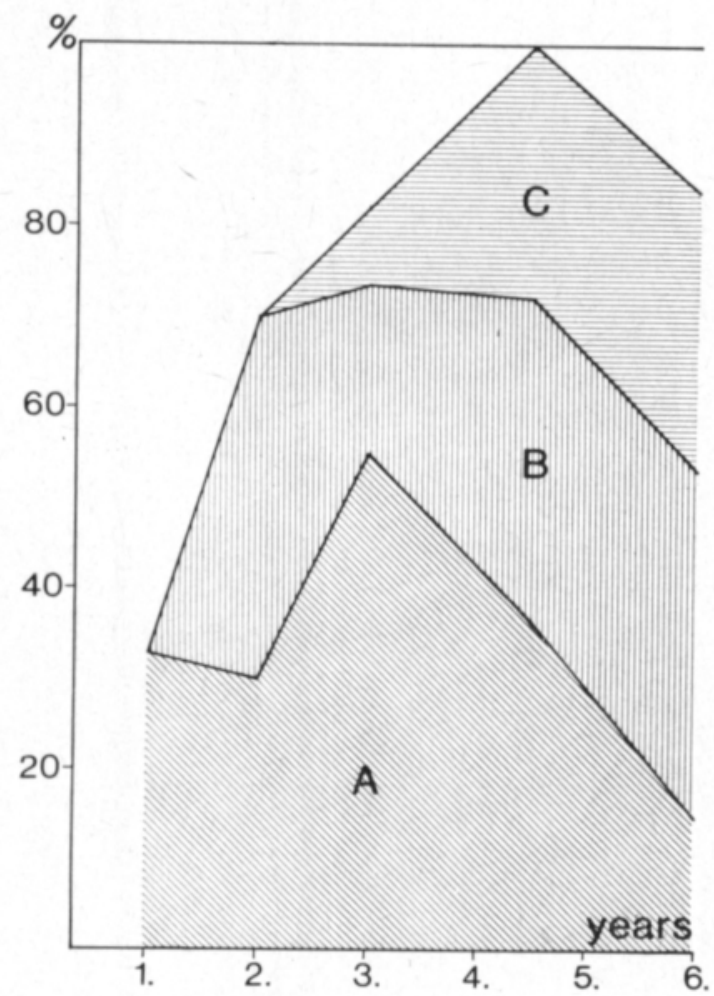

Fig. 2. The occupation of fields of different ages by the early summer aspect of leafhopper communities, as a percentage of the maximum number of fields. $\mathrm{A}=$ Balclutha punctata aspect, $\mathrm{B}=$ Megadelphax sordidula aspect, $\mathrm{C}=$ Doliotettix pallens aspect. 
tes as an adult, formed $64 \%$ of the leafhopper fauna of the aspect, other important species were Javesella spp. and Doliotettix pallens. This aspect occupied about $35 \%$ of the reserved fields in the study area.

2) Megadelphax sordidula aspect appeared on 2nd-6th year fields, which were situated usually on mineral ground. Moisture conditions in these fields were mostly intermediate or dry. Diplocolenus abdominalis, Doliotettix pallens and Balclutha punctata are the other three dominant species (D \% > 15). This aspect occurred on about $16 \%$ of the fields.

3) Doliotettix pallens aspect shows the greatest abundance of leafhoppers of the aspects described, the number of leafhoppers per 60 sweeps was about $5-10$ fold in comparison with the other aspects. It appeared on older, $3 \mathrm{rd}-6$ th year fields, favouring moist fields on organic soils. Besides Doliotettix pallens, no other dominants occurred in this aspect, second in abundance was Diplocolenus abdominalis. This aspect occupied about $31 \%$ of the fields.

The leafhopper fauna of high summer (suction samples) was also divided into three fairly distinct midsummer aspects, whose species composition, dominance relations and succession are given in Table 6 and Fig. 3.

Table 6. Dominance relations in the high summer aspect of leafhopper communities. $\mathrm{A}=$ Evacanthus interruptus aspect, $\mathrm{B}=$ Diplocolenus abdominalis aspect, $\mathrm{C}=$ Paluda flaveola aspect, $\mathrm{n}=$ number of adult leafhoppers on the average.

\begin{tabular}{|c|c|c|c|}
\hline & A & B & $\mathrm{C}$ \\
\hline 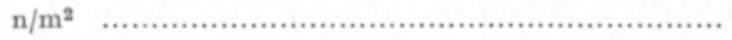 & 18.3 & 31.3 & 76.1 \\
\hline \multicolumn{4}{|l|}{ Dominance $\%$} \\
\hline 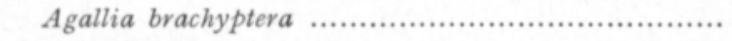 & - & - & 0 \\
\hline 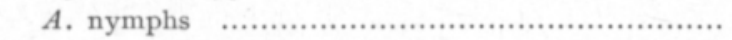 & 7 & 2 & 4 \\
\hline Aphrodes bicinctus ...................................... & - & - & 0 \\
\hline 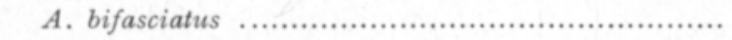 & 4 & 14 & 2 \\
\hline Arthaldeus pascuellus .................................... & 10 & 7 & 6 \\
\hline 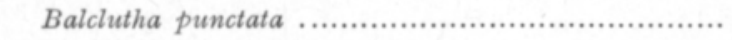 & - & - & 1 \\
\hline 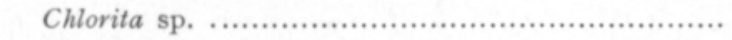 & - & - & 0 \\
\hline 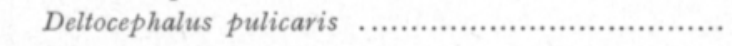 & 3 & - & - \\
\hline 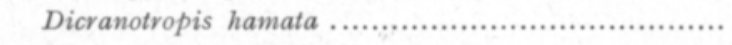 & - & 8 & 1 \\
\hline Diplocolenus abdominalis ............................. & 18 & 43 & 35 \\
\hline Doliotettix pallens ...................................... & - & - & 2 \\
\hline 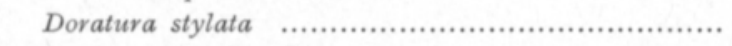 & - & - & 1 \\
\hline Elymana sulphurella ................................... & 3 & 1 & 1 \\
\hline 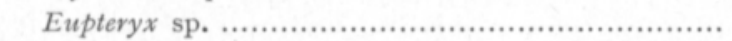 & - & - & 0 \\
\hline Evacanthus interruptus ................................ & 37 & 9 & 3 \\
\hline Javesella forcipata ..................................... & - & - & 1 \\
\hline 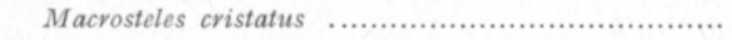 & - & - & 0 \\
\hline 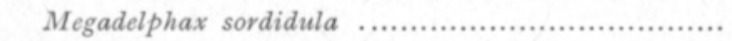 & - & 2 & 1 \\
\hline 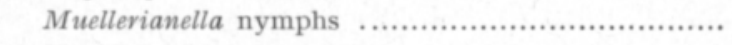 & - & - & 1 \\
\hline 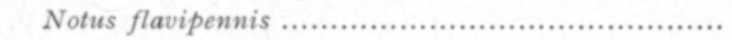 & - & - & 1 \\
\hline Paluda flaveola ............................................. & - & 5 & 20 \\
\hline P. preyssleri ............................................. & - & - & 4 \\
\hline Philaenus spumarius ..................................... & 14 & - & 2 \\
\hline Streptanus sordidus ...................................... & 4 & 2 & 6 \\
\hline 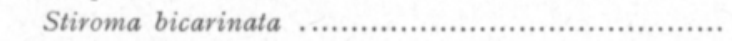 & 3 & 7 & 5 \\
\hline 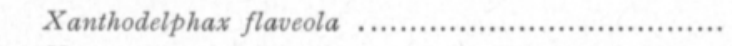 & - & - & 2 \\
\hline 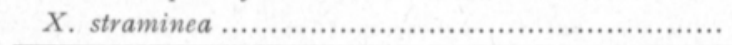 & - & - & 0 \\
\hline
\end{tabular}


1) Evacanthus interruptus aspect. This aspect appeared only on the youngest, 1st-2nd year fields, occupying about $12 \%$ of the studied fields. Other common species were Diplocolenus abdominalis, Philaenus spumarius, and Arthaldeus pascuellus.

2) Diplocolenus abdominalis aspect was common on older, 2nd -6th year fields, situated on relatively dry mineral ground. Diplocolenus was the only

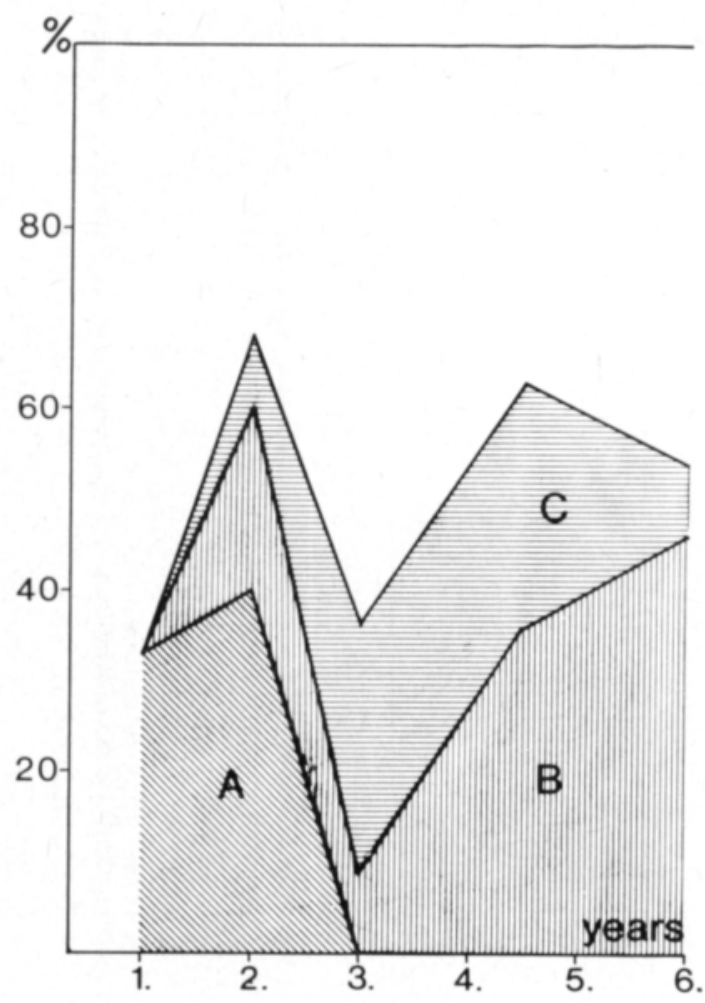

Fig. 3. The occupation of fields of different ages by the high summer aspect of leafhopper communities, as a percentage of the maximum number of fields. $\mathrm{A}=$ Evacanthus interruptus aspect, B $=$ Diplocolenus abdominalis aspect, $\mathrm{C}=$ Paluda flaveola aspect.

dominant species, other common species were Aphrodes bifasciatus, Evacanthus interruptus, Dicranotropis hamata, and Stiroma bicarinata. This aspect occupied about $16 \%$ of the fields.

3) Paluda flaveola aspect was typical on $3 \mathrm{rd}-6$ th year moist fields, which ware most often situated on organic soils. The aspect was very diverse, and the number of leafhoppers $/ \mathrm{m}^{2}$ was clearly the greatest. Paluda flaveola, P. preyssleri, and Diplocolenus abdominalis are probably the most common species of this aspect, others are e.g. Streptanus sordidus and Arthaldeus pascuellus. This aspect occupied about $26 \%$ of the fields in high summer.

The leafhopper communities could be detected by studying the occurrences of the described aspects in the same fields at different times (Table 7). The Balclutha punctata aspect of early summer was replaced mainly by the Evacanthus interruptus aspect in high summer, and these aspects are parts of the Evacanthus interruptus community. Similarly the Megadelphax sordidula aspect changed to the Diplocolenus abdominalis aspect and these are parts of the Diplocolenus abdominalis community. The Doliotettix pallens aspect changed 
Table 7. The relations between early and high summer aspects of the leafhopper communities, as a percentage of the maximum theoretical number of common fields in each comparison. The numbers in brackets indicate the number of fields occupied by this aspect.

\begin{tabular}{|c|c|c|c|}
\hline & $\begin{array}{c}\text { Evacanthus } \\
\text { interruptus } \\
\text { (6) }\end{array}$ & $\begin{array}{l}\text { Diplocolenus } \\
\text { abdominalis } \\
\text { (8) }\end{array}$ & $\begin{array}{c}\text { Paluda } \\
\text { flaveola } \\
\text { (13) }\end{array}$ \\
\hline 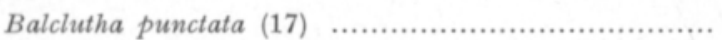 & 50 & 38 & 16 \\
\hline 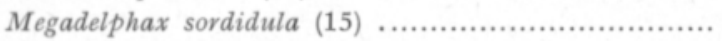 & 17 & 63 & 39 \\
\hline Doliotettix pallens $(8)$.................................... & 0 & 0 & 63 \\
\hline
\end{tabular}

Table 8. Dominance relations in the Apion communities. $\mathrm{A}=$ Apion simile community, $\mathrm{B}=$ Apion viciae community, $\mathrm{C}=$ Apion facetum community, $\mathrm{D}=$ Apion apricans community, $\mathrm{n}=$ number of individuals on the average.

\begin{tabular}{|c|c|c|c|c|}
\hline & A & B & $\mathrm{C}$ & $\mathrm{D}$ \\
\hline .......................................... & 13.7 & 7.3 & 20.5 & 20.0 \\
\hline \multicolumn{5}{|l|}{ Dominance $\%$} \\
\hline 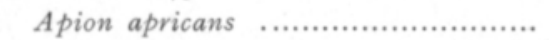 & 33 & - & - & 50 \\
\hline A. cerdo ..................................... & - & 5 & 19 & - \\
\hline 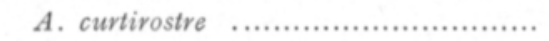 & 2 & 10 & 5 & 4 \\
\hline 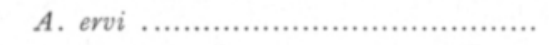 & - & 5 & - & 8 \\
\hline A. facetum .............................. & - & - & 51 & 4 \\
\hline A. flavipes ................................ & 6 & 5 & - & 25 \\
\hline A. marchicum ........................... & 4 & - & - & - \\
\hline A. simile $\quad$................................ & 43 & 5 & 7 & - \\
\hline 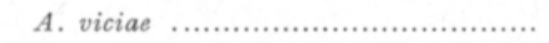 & 4 & 50 & 10 & - \\
\hline
\end{tabular}

to the Paluda flaveola aspect in high summer, and these are parts of the Paluda flaveola community.

The coleopteran genus Apion showed almost identical distribution in the sweep-net and the suction samples, and therefore no early and high summer aspects of the communities were separated. The QS method was applied to the data of high summer, and four different communities were identified (Table 8 and Fig. 4):

1) Apion simile community appeared mainly on young, 1st-3rd year reserved fields. These fields were most often intermediate in moisture, and were situated on coarse mineral ground. This was the most common of the Apion communities, appearing on $20 \%$ of the fields.

2) Apion viciae community appeared on $3 \mathrm{rd}-6$ th year fields, which were classified as wet or intermediate as to moisture, and which were often situated on organic soils. The abundance of the Apion species was distinctly lower in these fields than in the drier fields, only 7.3 individuals $/ \mathrm{m}^{2}$ on the average. $10 \%$ of the fields were representative of this community.

3) Apion facetum community was typical of old, 5 th -6 th year fields, which were dry or intermediate as to moisture. This community occupied about $14 \%$ of the fields. 
4) Apion apricans community was another community of old, dry fields situated on mineral ground. This community occupied about $6 \%$ of the fields, all of which were 6 th year fields.

About one third to one half of the fields ranked outside the presented classifications, partly because of the scarcity of animals in samples (especially in those from 1st year fields), and partly because their leafhopper and Apion communities were mixtures of the described communities, and thus could not be clearly differentiated with this method.

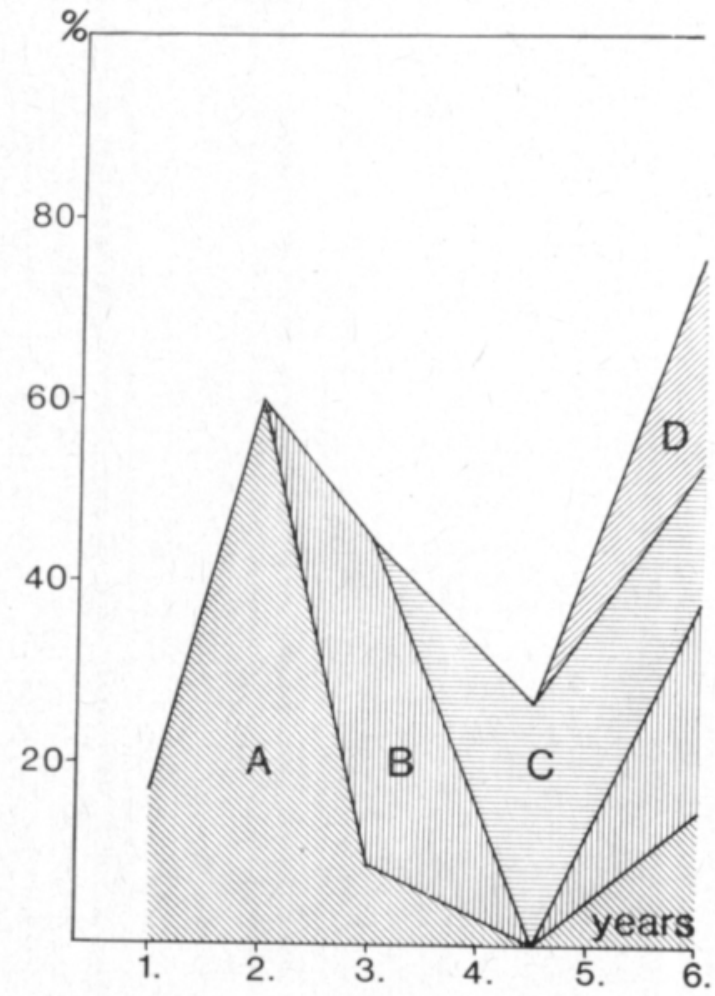

Fig. 4. The occupation of fields of different ages by the Apion communities, as a percentage of the maximum number of fields. $\mathrm{A}=$ Apion simile community, $\mathrm{B}=$ Apion viciae community, $\mathrm{C}=$ Apion facetum community, $\mathrm{D}=$ Apion apricans community.

\section{3.2. Relations to vegetational communities}

The vegetational communities of the studied fields have been described earlier (Hokkanen and RaAtikainen 1977). Table 9 shows the relations between them, the faunal aspects of the communities, and the faunal communities described in this work. Of the early summer aspects of leafhopper communities only the Megadelphax sordidula aspect showed a fairly clear affinity towards a vegetational community, the Phleum pratense community. The Doliotettix pallens aspect appeared almost equally on all older fields, seemingly independently of the vegetation communities. The high summer aspects of the leafhopper communities were more clearly associated to vegetational communities. The Evacanthus interruptus aspect was best represented on fields of the Phleum type. The Diplocolenus abdominalis aspect also favoured the Phleum type, but was frequent in the Elytrigia type fields as well. The greatest affinity ob- 
Table 9. The relations between vegetational and faunal communities, as a percentage of the maximum theoretical number of common fields in each comparison. The numbers in brackets indicate the number of fields occupied by the community.

\begin{tabular}{|c|c|c|c|c|c|}
\hline & $\begin{array}{l}\text { Galeopsis } \\
\text { type (4) }\end{array}$ & $\begin{array}{l}\text { Phleum } \\
\text { type (8) }\end{array}$ & $\begin{array}{c}\text { Elytrigia } \\
\text { type (7) }\end{array}$ & $\begin{array}{c}\text { Anthoxanthum } \\
\text { type (11) }\end{array}$ & $\begin{array}{c}\text { Deschampsia } \\
\text { type (5) }\end{array}$ \\
\hline Balclutha punctata (17) .... & 0 & 25 & 14 & 18 & 20 \\
\hline Megadelphax sordidula (15) & 0 & 50 & 29 & 36 & 20 \\
\hline Doliotettix pallens (8) ........ & 0 & 0 & 43 & 25 & 40 \\
\hline Evacanthus interruptus (6) . & 25 & 50 & 17 & 17 & 0 \\
\hline Diplocolenus abdominalis (8) & 0 & 38 & 29 & 13 & 0 \\
\hline Paluda flaveola (13) ......... & 0 & 0 & 29 & 36 & 80 \\
\hline Apion simile $(10)$.............. & 0 & 50 & 14 & 20 & 0 \\
\hline Apion viciae $(7)$.................. & 0 & 0 & 14 & 14 & 29 \\
\hline Apion facetum (5) ............. & 0 & 0 & 20 & 40 & 20 \\
\hline Apion apricans (3) ............. & 0 & 0 & 0 & 67 & 0 \\
\hline
\end{tabular}

served was that of the Paluda flaveola aspect to Deschampsia type fields; almost all Deschampsia fields were occupied by this leafhopper aspect.

All the Apion communities coincided with a vegetational community. The Phleum type was occupied by the Apion simile community - no other Apion communities were observed in those fields. The Apion apricans community appeared in Anthoxanthum type fields, as well as the Apion facetum community, but the latter was also observed in Elytrigia and Deschampsia fields, although to a lesser extent. The Apion viciae community favoured Deschampsia type fields, but occurred also in others except in the youngest successional communities.

\section{Discussion}

The occurrence of animals harmful to surrounding cultivations in reserved fields has been of great concern. Among the pests of cultivated plants, as listed by VAPPUla (1965), the following insect species or taxa were met in this study: Philaenus spumarius, Evacanthus interruptus, Javesella spp., Dicranotropis hamata, Corymbites pectinicornis, Galerucella tenella, Phyllotreta spp., Longitarsus spp., Chaetocnema spp., Apion flavipes, A. apricans, Polydrosus mollis, Sitona spp, Amaurosoma flavipes, and A. armillatum. According to RaAtikainen (1970), some leafhoppers are vectors of cereal viruses or mycoplasma, causing at times severe damage to cultivations. Of these species the following were met in reserved fields: Macrosteles cristatus, Javesella pellucida, J. obscurella, Dicranotropis hamata and Megadelphax sordidula. The proportion of these species in the total leafhopper fauna was about $20 \%$ in reserved fields, whereas in Finnish oats the proportion of such species is about $90 \%$ (RAATIKAINEN and VASARAINEN 1976).

The reason for the scarcity of most of the important pests in the reserved fields is probably the small proportion of suitable host plants, in comparison 
with e.g. cereals or timothy, and the competition of other species that may be better adapted to the conditions prevailing in reserved fields. The explanation may partly lie also in the distinct year-to-year fluctuations in the abundance of insects; according to MARKKULA (1975) in the summer of 1974 most pest groups were somewhat less abundant than the average. According to TörmäL and RaAtikainen (1976), the sampling times in this study coincided fairly well with the maximum abundances of arthropods, except for Coleoptera, which has its maximum later in the summer.

The populations of the field vole, Microtus agrestis, were fairly strong in the summer of 1974 (MARKKúla 1975), and especially strong in Central Finland, which can be seen from the severe damage in the winter of 1974/75 (TeIvainen 1975). In the study of Myllymäki and PaAsikallio (1976), the catch with the small quadrat method in seed orchards on forest ground was a total of 5.3 individuals per quadrat, 3.7 of them being Microtus agrestis. In the summer of 1974 the average catch in Central Finland was about 7-10 individuals per quadrat (Myllymäki, pers. com.). The catch from reserved fields was considerably lower, exactly 3.3 individuals per quadrat, and only 1.1 of them were Microtus agrestis. On about $12 \%$ of the fields the catch of small mammals equalled the average from Scots pine seed orchards (at least 7 ex./SQ).

TörmäLÄ and RAatikainen (1976) describe three seasonal aspects of leafhopper communities from a reserved field. According to their timing, the seasonal aspects described in this study represent the early summer aspect and the mid-late summer aspect. The early summer aspect of TöRMÄLÄ and RAATIKAINEN (1976) represents clearly the Doliotettix pallens aspect described in this study, but the mid-late summer aspect does not yet rank clearly into the Paluda flaveola aspect, because the samples were taken so early.

KontKanen (1950) gives information about the seasonal aspects of leafhopper communities as well as their biotope requirements. Also he distinguished communities living in dry, fresh and wet biotopes. Although the species composition in his study area differed widely from ours, the community he describes from fresh biotopes (the Doliotettix pallens community) in the early summer aspect corresponds very well with our Doliotettix pallens aspect. Of his high summer communities the one living on moist - fresh biotopes (the Philaenus spumarius - Arthaldeus pascuellus - Elymana sulphurella -community) resembles best the leafhopper fauna of reserved fields.

RaAtikainen and Vasarainen (1976) describe the leafhopper communities of Finnish oat fields. None of their communities are similar to the communities on reserved fields, because the species composition is quite different.

The occurrence and the true nature of the so-called faunal communities have been widely discussed for a long time (see e.g. PrICE 1975). However, certain species do show a tendency to occur more or less together, and can thus be considered to form a community. The reason for the co-existence may be e.g. the same food plants, the same physical environment requirements, similar pressure from the enemies (predators, parasites, etc), or some other factor.

RAATIKAINEN and VASARAINEN (1976) present information about the ecological requirements, e.g. host plants, of many leafhopper species, and RAATIKAINEN et al. (1977) show the dependence of Philaenus spumarius on certain 
plant community types. MARKKULA and MyLlymäKI (1958) list the host plants for many Apion species and show that different Apion faunas exist in different types of leys. KontKanen (1950) discussed the relation between leafhopper communities and vegetational communities, but he could not clearly show their mutual dependence. Although there is a definite relationship and a need for co-existence between e.g. a leafhopper and its host plant, these relations differ on the one hand, and overlap on the other hand, so much from one species to another that the dependence of an animal community on a vegetational community becomes much looser than the actual species-to-species relations. The data of this study likewise support this view, for although both the animal and the vegetational communities could be described relatively distinctly, their mutual dependence was rather weak, and their occurrences overlapped over a wide range.

From the changes that could be ascertained with years in the fauna, both at the species, the aspect, and the community level, it can be concluded that succession proceeds in a reserved field towards the conditions of natural meadows, and that the most drastic changes take place within a few years from reservation - after that the changes get slower and succession proceeds less vigorously. During the first years most of the important pest species decrease and the species of natural meadows increase their share. Especially important is the increasing proportion of predators (like Araneida, Hymenoptera) at the expense of their prey (e.g. Diptera). Similar changes were observed also in the study of the Vistula Valley in Poland (e.g. KaJAK et al. 1971).

Acknowledgements. We are grateful to Mr. Timo Törmälä, Ph. Lic., who took part in the field and laboratory work. The financial support from the National Research Council for Sciences is greatly appreciated.

\section{REFERENCES}

AndrzejewskA, L. 1971. Productivity investigation of two types of meadows in the Vistula Valley. VI. Production and population density of leafhopper (Homoptera - Auchenorrhyncha) communities. Ekol. Pol. 19: 151-172.

AnoN. 1975. Monthly review of agricultural statistics 1975, 1:1-56.

GyllenberG, G. 1969. The energy flow of Chorthippus parallellus (Zett.) (Orthoptera) population on a meadow in Tvärminne, Finland. Acta Zool. Fenn. 123: 1-74.

HANSEN, V. 1965. Biller XXI. Snudebiller. Danmarks fauna 69: 1-524. København.

Heikinheimo, O. \& RaAtikainen, M. 1962. Comparison of suction and netting methods in population investigations concerning the fauna of grass leys and cereal fields, particularly in those concerning the leafhopper Calligypona pellucida (F.). Publ. Finn. State Agric. Res. Board 191: 1-31.

Hokkanen, H. \& RaAtikarnen, M. 1977. Yield, vegetation and succession in reserved fields in Central Finland. J. Scient. Agric. Soc. Finl. 49: 221-238.

Huhta, V. \& RaAtikainen, M. 1974. Spider communities of leys and winter cereal fields in Finland. Ann. Zool. Fenn. 11: 97-104.

Jürisoo, V. 1964. Agro-ecological studies on leafhoppers (Auchenorrhyncha, Homoptera) and bugs (Heteroptera) at Ekensgåd farm in the province of Hälsingland, Sweden. Stat. Växtskyddsanst. Medd. 13,101: 1-147.

Kajak, A., Breymeyer, A. \& Petal, J. 1971. Productivity investigation of two types of meadows in the Vistula Valley. XI. Predatory arthropods. Ekol. Pol. 19: 223-233. 
KontKanen, P. 1950. Quantitative and seasonal studies on the leafhopper fauna of the field stratum on open areas in North Karelia. Ann. Zool. Soc. 'Vanamo' 13, 8: 1-91.

Koponen, T. 1972. Peltomyyräpopulaation rakenteesta. Metsäntutkimuslaitos. Metsänviljelyn Koeaseman Tied. 4:1-20.

Laitinen, T. \& RaAtikainen, M. 1975. Seasonal aspects of beetle fauna occurring in oats in Western-Finland. Ann. Agric. Fenn. 14: 203-209.

Linnavuori, R. 1969 a. Nivelkärsäiset IV. Kaskaat 1. Anim. Fenn. 12: 1-244. Porvoo-Helsinki.

- 1969 b. Nivelkärsäiset IV. Kaskaat 2. Anim. Fenn. 13: 1-312. Porvoo-Helsinki.

Marккula, M. 1975. Viljelykasvien tuhoeläimet 1974. Koetoim. ja Käyt. 32: 9.

- - \& Mүlцyмäкi, S. 1958. The composition of the Apion (Col., Curculionidae) population of grassland legumes and some wild leguminous plants. Ann. Ent. Fenn. 24: 97-124.

Myllymäki, A. \& PaAsikallio, A. 1976. Scots pine seed depredation by small mammals, as revealed by radioactive tagging of the seeds. Ann. Agric. Fenn. 15: 89-96.

- - , Paasikallio, A., Pankakoski, E. \& Kanervo, V. 1971. Removal experiments on small quadrats as a means of rapid assesment of the abundance of small mammals. Ann. Zool. Fenn. 8: 177-185.

Olechowicz, E. 1971. Productivity investigation of two types of meadows in the Vistula Valley. VIII. The number of emerged Diptera and their elimination. Ekol. Pol. 19: 183-195.

Price, P. W. 1975. Insect ecology. 514 p. New York.

RAatikainen, M. 1970. Viljojen virukset ja kaskaat. (Summary: Virus diseases of cereals and leafhoppers). Luonnon Tutkija 75: 65-74.

- 1971. Seasonal aspects of leafhopper (Hom., Auchenorrhyncha) fauna in oats. Ann. Agric. Fenn. 10: 1-8.

- $-\&$ Vasarainen, A. 1976. Composition, zonation and origin of the leafhopper fauna of oatfields in Finland. Ann. Zool. Fenn. 13:1-24.

- - , Halkкa, O., Vasarainen, A. \& Halkкa, L. 1977. Abundance of Philaenus spumarius in relation to types of plant community in the Tvärminne archipelago, southern Finland. Biol. Res. Rep. Univ. Jyväskylä 3: 3-38.

Sirvonen, L. 1974. Pohjolan nisäkkäät. 196 p. Helsinki.

Tervarnen, T. 1975. Myyräkanta kehittymässä huippuun Keski-Suomessa. Metsälehti 42, 31: 8 .

TöRMÄLÄ, T. 1977. Effects of mowing and ploughing on the primary production and flora and fauna of a reserved field in Central Finland. Acta Agric. Scand. 27: 253-264.

- - Ноккаnen, H. 1976. Pakettipeltojen ja niiden reuna-alueiden linnustosta Keski-Suomessa. Keski-Suomen Linnut 1: 44-47.

- - \& Rantikainen, M. 1976. Primary production and seasonal dynamics of the flora and fauna of the field stratum in a reserved field in Middle Finland. J. Scient. Agric. Soc. Finl. 48: 363-385.

VAppula, N. A. 1965. Pests of cultivated plants in Finland. Acta Ent. Fenn. 19: 1-239.

Ms received January 3, 1978 


\title{
Pakettipeltojen kenttäkerroksen eläinyhteisöistä ja niiden seuraannosta Keski-Suomessa
}

\author{
Heikкi Ноккаnen ja Mrккo RaAtikainen \\ Jyväskylän yliopisto, Biologian laitos
}

Tutkimuksen tarkoituksena oli selvittää, mitä eläimiä ja eläinyhteisöjä pakettipelloilla esiintyy ja miten eläinten runsaudet ja eläinyhteisöt muuttuvat paketointiaikana. Erityistä huomiota kiinnitettiin tuhoeläimiin.

Tutkimuskohteina oli 20 tilan 51 peltolohkoa, jotka poimittiin otannalla Jyväskylästä ja sen ympäristökunnista. Kultakin lohkolta otettiin v. 1974 kesäkuun alussa neljä 15 haavinvedon näytettä ja heinäkuun puolivälissä neljä $0,10 \mathrm{~m}^{2}:$ imunäytettä kenttäkerroksen niveljalkaisista. Elokuun lopulla suoritettiin lohkoilla pikkunisäkkäiden ruutupyynti 1224 loukkuyönä.

Keskikesällä pakettipeltojen kenttäkerroksesta tavattiin keskimäärin 210 niveljalkaista/m². Niistä oli kaskaita $42 \%$, pistiäisiä $18 \%$, kovakuoriaisia $14 \%$ ja muita yhteensä $26 \%$. Nurmen jälkeen paketoiduilla pelloilla oli eläimiä runsaammin kuin avoviljelyksen jälkeen paketoiduilla pelloilla. Useimpien ryhmien runsaudet kasvoivat peltojen paketissaoloiän kasvaessa, mutta lähes kaikkien merkittävien tuholaisten runsaudet kuitenkin pienenivät peltojen vanhetessa.

Pikkunisäkkäistä runsaimmat olivat metsäpäästäinen (57 \% kaikista) ja peltomyyrä (32 \%). Niiden tiheydet olivat kuitenkin keskimäärin paljon pienemmät pakettipelloilla kuin läheisillä männyn siemenviljelyksillä.

Kaskasaineistoista erottui kolme yhteisöä. Yksi niistä esiintyi nuorilla, (1. - 3. vuotta paketissa olleilla) pelloilla, yksi vanhoilla (2.-6. vuoden) kuivahkoilla ja yksi vanhoilla kosteilla pelloilla.

Alku- ja keskikesän kausiyhteisōt vastasivat esiintymispaikoiltaan toisiaan niin hyvin, että kyseessä selvästikin olivat samojen yhteisöjen vuodenaikaisaspektit. Kaskasyhteisōjen lisäksi kuvattiin neljä nirppuyhteisöä. Minkään kuvatun eläinyhteisön riippuvuus peltojen kasviyhteisöistä ei ollut kovin selvä, vaan monet yhteisöt esiintyivät näennäisen itsenäisesti usealla eri kasvillisuustyypillä.

Tulokset osoittavat, että pakettipellot eivät yleensä ole merkittäviä tuhoeläinten leviämiskeskuksia, koska vahingollisten lajien tiheydet ovat niissä alhaisia. Ne voivat kuitenkin olla joidenkin lajien, esim. timoteikärpästen, osalta tärkeitä suoja- ja lisääntymispaikkoja.

Eniten haittaa lienee peltomyyristä, joiden tiheydet pakettipelloilla vaihtelevat pellon kosteuden, kasvillisuuden yms. mukaan. Huippuarvot eivăt kuitenkaan saavuttaneet esimerkiksi männyn siemenviljelyksiltä todettuja arvoja. Paikallinen merkitys voi kuitenkin joskus olla huomattava. 